\title{
Interferon Alpha Receptor 2 Expression by Peripheral Blood Monocytes in Patients with a High Viral Load of Hepatitis C Virus Genotype 1 Showing Substitution of Amino Acid 70 in the Core Region
}

\author{
Koji Ishii ${ }^{a}$ Mie Shinohara ${ }^{a}$ Misato Sawa ${ }^{a}$ Michio Kogame ${ }^{a}$ Katsuya Higamia $^{a}$ \\ Masanari Sano $^{\text {b }}$ Toshisuke Morita $^{\text {b }}$ Yasukiyo Sumino $^{a}$ \\ a Department of Internal Medicine, Division of Gastroenterology and Hepatology, and \\ ${ }^{b}$ Department of Laboratory Medicine, Toho University School of Medicine, Faculty of Medicine, Tokyo, Japan
}

\section{Key Words}

Chronic hepatitis $C \cdot$ Amino acid substitution - Core region Interferon- $\alpha$ receptor $2 \cdot$ Peripheral blood leukocyte before and also 3, 7, and 28 days after starting therapy. Conclusions: Mutation of HCV was related to lower IFNAR-2 expression by Mo before and after starting therapy.

Copyright $\odot 2009$ S. Karger AG, Basel

\section{Introduction}

Interferon (IFN) is an essential component of current treatment for chronic hepatitis $\mathrm{C}(\mathrm{CHC})$. The most effective therapy available at present is the combination of pegylated (PEG)-IFN and ribavirin (RBV) [1], and achieving serum hepatitis $\mathrm{C}$ virus (HCV)-RNA negativity by week 12 of treatment (early virologic response: EVR) is an important predictor of a sustained virologic response in $\mathrm{CHC}$ patients with genotype $1 \mathrm{~b}$ and a high viral load $[2,3]$. HCV with substitutions of amino acid (aa) 70 in the core region has been reported to be more difficult to treat than HCV without aa 70 substitution $[4,5]$.

The HCV core protein has been reported to interfere with intracellular IFN signaling [6, 7]. When IFN initiates its intracellular signal transduction pathway, Jak1 and STAT 2 kinases are activated and in turn phosphorylate STAT1 and STAT2. Association of Jak1 with STAT1

\section{KARGER}

Fax +4161306 1234 E-Mail karger@karger.ch www.karger.com
(ㄷ) 2009 S. Karger AG, Basel

0300-5526/10/0532-0105\$26.00/0

Accessible online at:

www.karger.com/int
Koji Ishii, MD

Department of Internal Medicine, Division of Gastroenterology and Hepatology 6-11-1 Omorinishi, Otaku

Tokyo 143 (Japan)

Tel. +81 33762 4151, Fax +81 33763 8542, E-Mail iskoji377@med.toho-u.ac.jp 
Table 1. Background of patients with wild and mutant aa 70

\begin{tabular}{llll}
\hline & Wild & Mutant & p value \\
\hline Number of patients & 23 & 20 & \\
Age, years & $56(43-67)$ & $55(32-66)$ & 0.06 \\
Sex, M/F & $12 / 11$ & $7 / 13$ & 0.26 \\
Serum & & & \\
$\quad$ aa 91 (mutant/wild) & $4 / 19$ & $3 / 17$ & 0.85 \\
$\quad$ HCV-RNA, log copies/ml & $6.6(6.0-6.7)$ & $6.4(5.8-6.6)$ & 0.06 \\
$\quad$ AST, IU/ml & $55(29-89)$ & $56(27-136)$ & 0.27 \\
$\quad$ ALT, IU/ml & $55(30-125)$ & $68(35-188)$ & 0.13 \\
Peripheral blood & $5,600(4,120-7,160)$ & $4,500(3,650-6,740)$ & 0.02 \\
$\quad$ WBC, / $\mu$ l & $459(410-505)$ & $445(404-503)$ & 0.18 \\
$\quad$ RBC, $\times 10^{4} / \mu l$ & $14.2(12.3-15.8)$ & 0.36 \\
$\quad$ PLT, $\times 10^{4} / \mu l$ & & & \\
Pathological findings & $14.7(13.3-15.9)$ & $9 / 10 / 0 / 1$ & 0.49 \\
$\quad$ Activity $1 / 2 / 3 /$ none & $6 / 15 / 1 / 1$ & $10 / 3 / 3 / 3 / 1$ & 0.51 \\
$\quad$ Fibrosis $1 / 2 / 3 / 4 /$ none & $7 / 5 / 8 / 2 / 1$ & & \\
Previous IFN therapy & $15 / 8$ & $12 / 8$ & 0.72 \\
$\quad$ No/yes & & & \\
\hline
\end{tabular}

Unless otherwise indicated the values are medians with ranges in parentheses.

Ranges represent the 10-90th percentile.

initiates phosphorylation of STAT1, after which phosphorylated STAT1 forms a heterotrimeric complex together with phosphorylated STAT2 and IFN regulatory factor 9. This complex is known as IFN-stimulated gene (ISG) factor 3 (ISGF3), and it undergoes translocation to the nucleus where it binds to IFN-stimulated response element (ISRE) and upregulates a large number of ISGs including 2',5'oligoadenylate synthetase (2-5AS) [810].

The effect of aa substitutions in the core region of HCV on intracellular signal transduction induced by IFN has not been investigated. Since signaling is initiated following the binding of IFN to receptors on the plasma membrane of target cells, the role of IFN receptors should also be worth investigating. The type I IFN receptor consists of at least two subunits, which are referred to as IFNAR-1 (IFN- $\alpha$ receptor) and IFNAR-2 (IFN- $\alpha / \beta$ receptor) $[11,12]$. Recent studies have demonstrated a significant correlation between hepatic expression of this receptor and the response of CHC patients to IFN [1316]. It has also been reported that expression of messenger RNA (mRNA) for IFNAR-2 by peripheral blood mononuclear cells is correlated with the hepatic expression of this mRNA [17]. However, determining the level of expression of functional IFN receptors would be more useful, if this was possible.
Recently, a rapid flow cytometry method for measuring IFNAR-2 in small samples of whole blood has been established [18], and it can also be used to evaluate IFNAR-2 protein expression by leukocyte subsets [19]. The aim of the present study was to clarify whether changes in IFNAR-2 expression by peripheral blood Mo up to day 28 of IFN treatment differed between patients with substitution of aa 70 in the core region of HCV and those without this substitution.

\section{Patients and Methods}

The subjects were 43 patients with genotype $1 \mathrm{~b}$ CHC, including 19 men and 24 women ranging (10-90th percentiles) from 41 to 67 (median 56) years of age (table 1). Written informed consent for the study was obtained from each patient. All patients were positive for anti-HCV antibody by a third-generation enzyme-linked immunosorbent assay (ELISA) and for serum HCV-RNA quantified by Taqman PCR method (Roche Diagnostics, Tokyo, Japan; detection limit $15 \mathrm{IU} / \mathrm{ml}$ ). Serum levels of HCV-RNA in the subjects ranged (10-90th percentiles) from 5.8 to 6.7 (median 6.5) log kilocopies/ml. Patients known to be homosexual or intravenous drug users, those positive for hepatitis B surface antigen (HBs-Ag) or antinuclear antibody, and those with metabolic liver dysfunction, diabetes mellitus, and renal dysfunction were excluded.

Detection of aa substitutions in the HCV core region was performed using the previously reported method [4, 5], and the patients were divided into 2 groups on the basis of the findings. $\mathrm{Pa}-$ 
tients with substitution of aa 70 in the core region of HCV were assigned to the mutant group and patients without this substitution were assigned to the wild group.

Of the 43 patients, 41 had undergone liver biopsy before combination therapy, and the tissue specimens thus obtained were graded according to the histology activity index (HAI) of Knodell et al. [20], after which the specimens were divided into 3 groups according to Desmet et al. [21]: grade 1 for HAI scores of 1-3; grade 2 for HAI scores of 4-8, and grade 3 for HAI scores of 9 or more. The specimens were also divided into 4 groups from stage 1 to stage 4 based on the fibrosis score of Desmet et al. [21].

\section{IFN Regimens}

All patients received IFN therapy after giving informed consent. PEG-IFN- $\alpha-2 b$ (Pegintron ${ }^{\circledR}$, Schering Plough Pharmaceutical Co. Ltd., Tokyo, Japan) was given intramuscularly for 40 weeks in a weekly dose adjusted for body weight according to the manufacturer's instructions $(<45 \mathrm{~kg}=60 \mu \mathrm{g} /$ dose, $46-60 \mathrm{~kg}=80$ $\mu \mathrm{g} / \mathrm{dose}, 61-75 \mathrm{~kg}=100 \mu \mathrm{g} / \mathrm{dose}, 76-90 \mathrm{~kg}=120 \mu \mathrm{g} / \mathrm{dose}$, and $>91 \mathrm{~kg}=120 \mu \mathrm{g} / \mathrm{dose}) . \mathrm{RBV}$ (Rebetol ${ }^{\circledR}$, Schering Plough Pharmaceutical Co. Ltd) was given orally for 48 weeks in daily doses adjusted for body weight according to manufacturer's instructions $(<60 \mathrm{~kg}=600 \mathrm{mg} /$ day, $61-80 \mathrm{~kg}=800 \mathrm{mg} /$ day, and $>81 \mathrm{~kg}=1,000$ $\mathrm{mg} /$ day).

If serum HCV-RNA quantified by PCR was negative in week 12, this was defined as an EVR. If serum HCV-RNA quantified by PCR was positive in week 12, this was defined as a non-EVR.

\section{Assays}

Blood samples were collected from all patients before and 3, 7, 14 , and 28 days after the start of IFN therapy. Then IFNAR-2 expression by peripheral leukocytes was determined using flow cytometry to measure the mean fluorescence intensity (MFI) after staining with anti-IFNAR-2 antibody, as reported previously [18].

Serum 2-5AS activity was assessed before and 3, 7, 14, and 28 days after the start of therapy with an RIA (Eiken Immunochemical Laboratory, Tokyo, Japan), that had a detection limit of 10 $\mathrm{pmol} / \mathrm{dl}$.

\section{Comparisons Performed}

We investigated the following points: (1) comparison of the EVR rate between the wild and the mutant groups; (2) comparison of IFNAR-2 expression by peripheral blood Mo and serum 2-5AS levels between the wild and mutant groups before therapy and also 3, 7, 14, and 28 days after the start of therapy, and (3) comparison of IFNAR-2 expression by peripheral blood Mo and serum 2-5AS levels between the EVR and non-EVR patients from the wild and mutant groups before therapy, and also 3, 7, 14, and 28 days after the start of therapy.

\section{Statistical Analysis}

Results in table 1 are presented as the median and the 10-90th percentiles. The $\chi^{2}$ test was used to compare characteristics between the groups.

Data shown in the figures $1-3$ are expressed as the mean \pm $\mathrm{SD}$. Comparisons between 2 groups were done by the nonparametric Mann-Whitney test or the $\chi^{2}$ test. A probability value of $<0.05$ was considered to indicate statistical significance.

IFNAR-2 Expression by Monocytes in CHC Patients

\section{Results}

\section{EVR Rates}

The EVR rate of the wild group was significantly higher than that of the mutant group $(16 / 23,70 \%$, vs. $7 / 20$, $35 \% ; \mathrm{p}<0.05$ by the $\chi^{2}$ test).

\section{Changes in IFNAR-2 Expression and Serum 2-5AS}

The MFI of Mo was always higher in the wild than in the mutant group during the study period. The MFI of Mo before therapy and also 3, 7, and 28 days after the start of therapy was significantly higher in the wild than in the mutant group ( $p<0.05$ by the Mann-Whitney test; fig. 1a).

There were no significant differences in the serum level of 2-5AS between the wild and mutant groups throughout the study period (fig. 1b).

\section{Changes in IFNAR-2 and Serum 2-5AS in EVR or \\ Non-EVR Patients from the Wild Group}

The MFI of Mo was always higher in the EVR patients than in the non-EVR patients during the study period, although the difference did not reach statistical significance (fig. $2 \mathrm{a}$ ).

Serum levels of 2-5AS were always higher in the EVR than in the non-EVR patients during the study period. Serum levels of 2-5AS were significantly higher in the EVR than in the non-EVR patients on days 3, 7, 14, and 28 of treatment ( $p<0.05$ by the Mann-Whitney test; fig. 2b).

\section{Changes in IFNAR-2 and Serum 2-5AS in EVR or}

Non-EVR Patents from the Mutant Group

The MFI of Mo did not differ between the EVR and non-EVR patients throughout the study period (fig. 3a).

Serum levels of 2-5AS were significantly higher in the EVR than in the non-EVR patients only on day 3 of treatment ( $p<0.05$ by the Mann-Whitney test; fig. 3b).

\section{Discussion}

It has been reported that $\mathrm{HCV}$ core protein influences IFN signaling in target cells such as hepatocytes and peripheral blood mononuclear cells. However, substitution of aa 70 in the core region of $\mathrm{HCV}$ is not known to affect intracellular signal transduction by IFN. The present study demonstrated that IFNAR-2 expression by Mo in patients with aa 70 substitution in the core region of $\mathrm{HCV}$ (mutant) was lower than that in patients without aa 70 


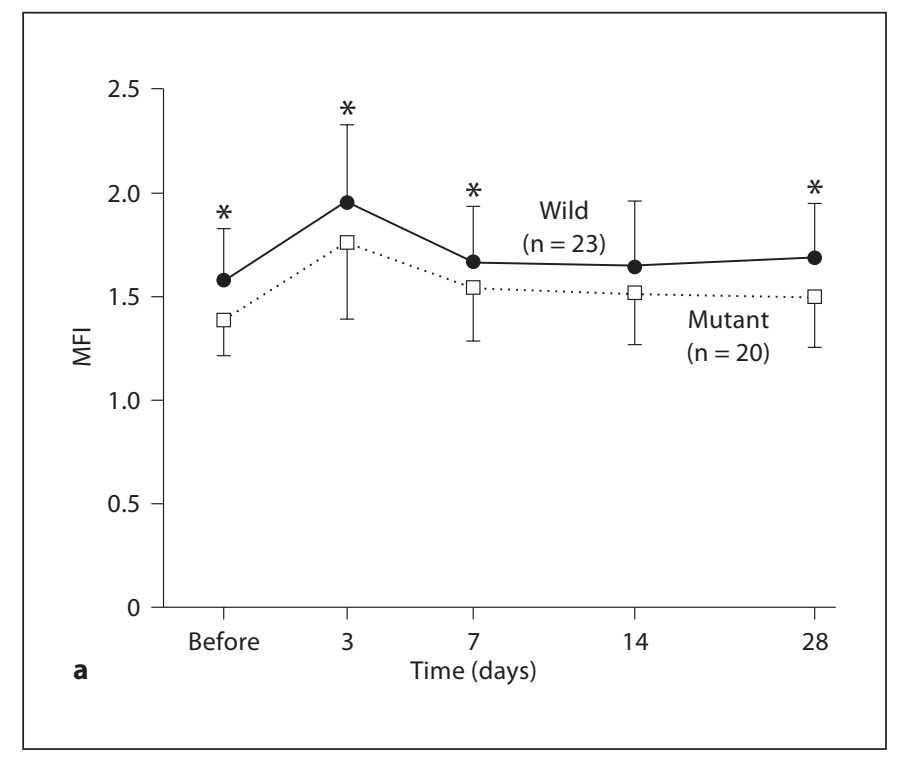

Fig. 1. a IFNAR-2 expression by Mo in all patients. The solid line shows the mean IFNAR-2 expression by peripheral blood Mo $(+\mathrm{SD})$ in patients without aa 70 substitution in the HCV core region (wild). The dotted line shows mean IFNAR-2 expression by Mo (-SD) in patients with aa 70 substitution in the HCV core region (mutant). ${ }^{*}$ Significant difference $(\mathrm{p}<0.05)$ between the wild

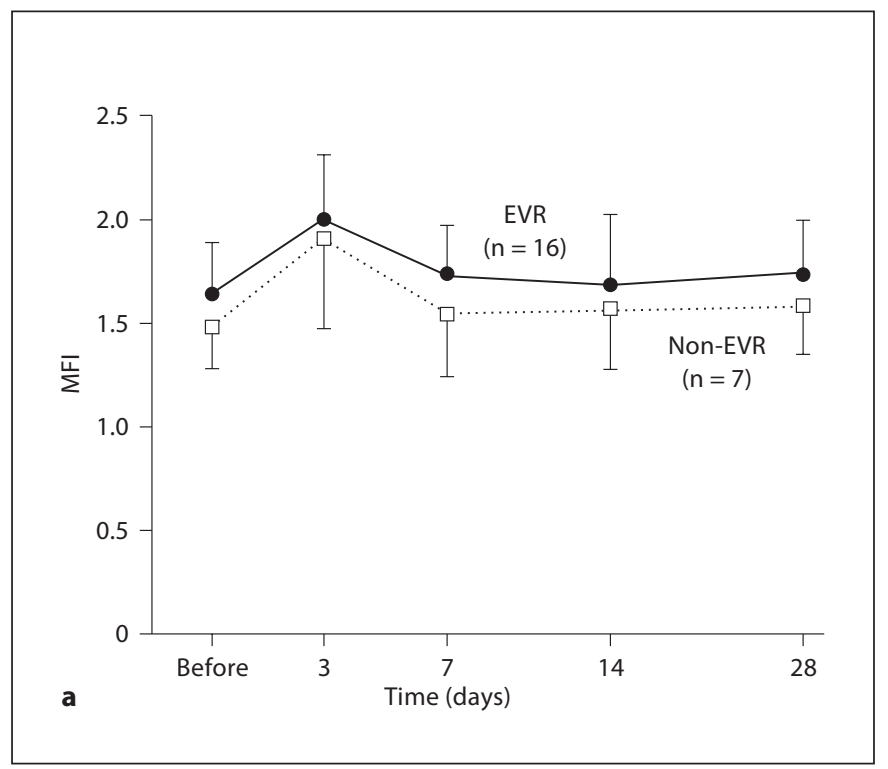

Fig. 2. a IFNAR-2 expression by Mo in the wild group. The solid line shows the mean IFNAR-2 expression by peripheral blood Mo (+SD) in the patients from the wild group who obtained an early virologic response (EVR). The dotted line shows the mean IFNAR-2 expression by Mo (-SD) in patients from the wild group who did not obtain EVR (non-EVR). No significant difference $(p>0.05)$ between the EVR and non-EVR patients from the wild

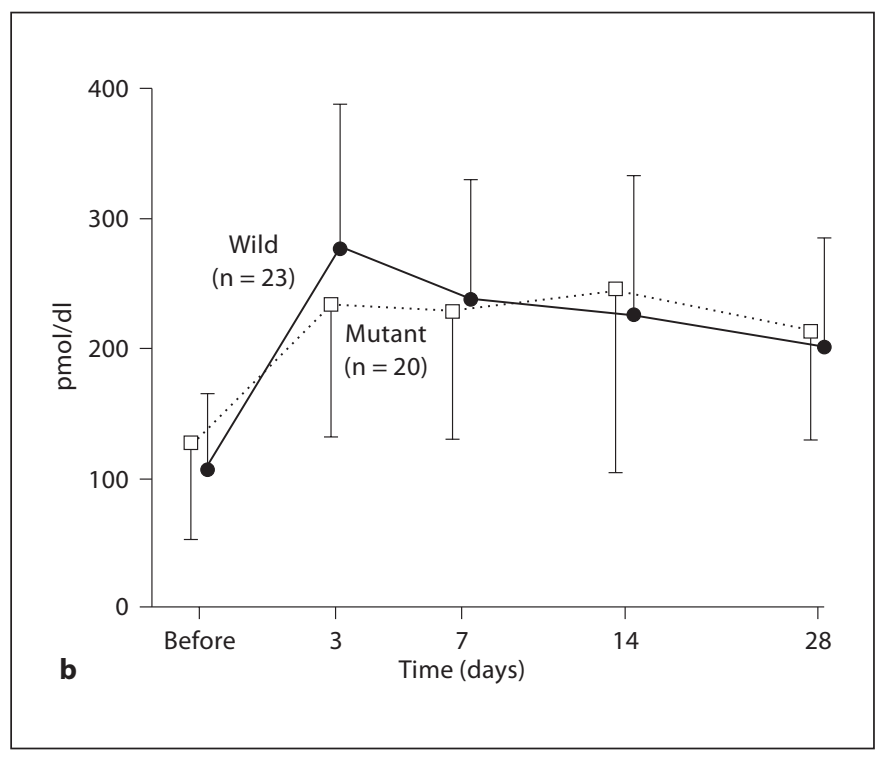

and mutant groups. b Serum 2-5AS in all patients. The solid line shows the mean serum 2-5AS level (+SD) in the wild group. The dotted line shows the mean serum 2-5AS level (-SD) in the mutant group. No significant difference $(\mathrm{p}>0.05)$ between the wild and mutant groups.

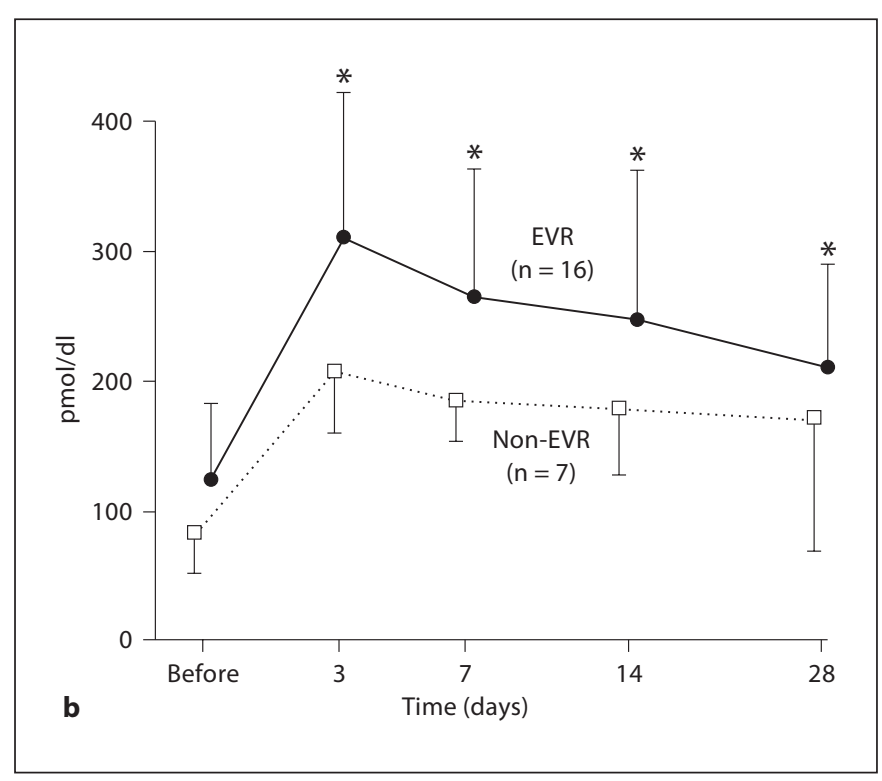

group. b Serum 2-5AS activity in the wild group. The solid line shows mean serum 2-5AS level (+SD) in EVR patients from the wild group. The dotted line shows mean serum 2-5AS level (-SD) in non-EVR patients from the wild group. ${ }^{*}$ Significant difference $(\mathrm{p}<0.05)$ between the EVR and non-EVR patients from the wild group. 


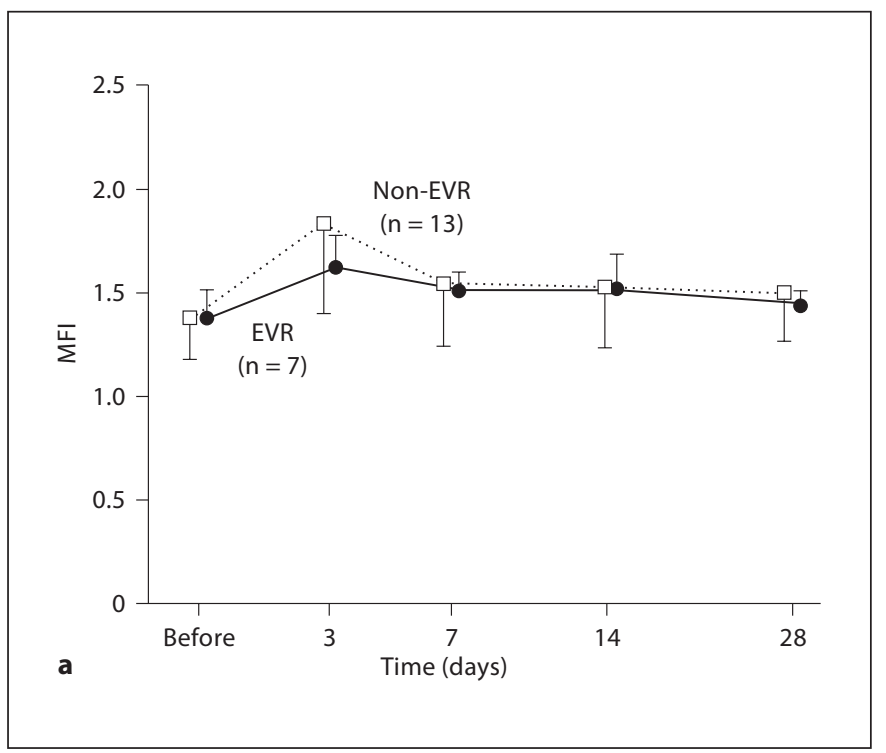

Fig. 3. a IFNAR-2 expression by Mo in the mutant group. The solid line shows the mean IFNAR-2 expression by peripheral blood Mo (+SD) in patients from the mutant group who obtained an early virologic response (EVR). The dotted line shows the mean IFNAR-2 expression by Mo (-SD) in patients from the mutant group who did not obtain EVR (non-EVR). No significant difference $(p>0.05)$ between the EVR and non-EVR patients

substitution in the core region (wild). Therefore, aa 70 substitution in the HCV core region was suggested to be associated with reduced IFNAR-2 expression by Mo and, to our knowledge, this is the first report of such a finding.

It is impossible to observe serial changes in IFNAR-2 expression in the liver after combination therapy with PEG-IFN and RBV in CHC patients. Since hepatic expression of IFNAR-2 and its expression by peripheral blood mononuclear cells are reported to be correlated [17], it could be valuable to observe serial changes in receptor expression on peripheral blood Mo. Further, it is thought that assessing expression of the functional IFN receptor is more useful than determining expression at the mRNA level. IFN receptor protein located on the cell membrane is functional, while intracellular receptor protein is not, and flow cytometry makes it possible to determine the amount of a particular receptor protein expressed on the surface of peripheral blood Mo in $\mathrm{CHC}$ patients.

In the present study, IFNAR-2 expression by peripheral blood Mo was consistently higher in patients without aa 70 substitution than in those with aa 70 substitution after the start of combination therapy for $\mathrm{HCV}$, because

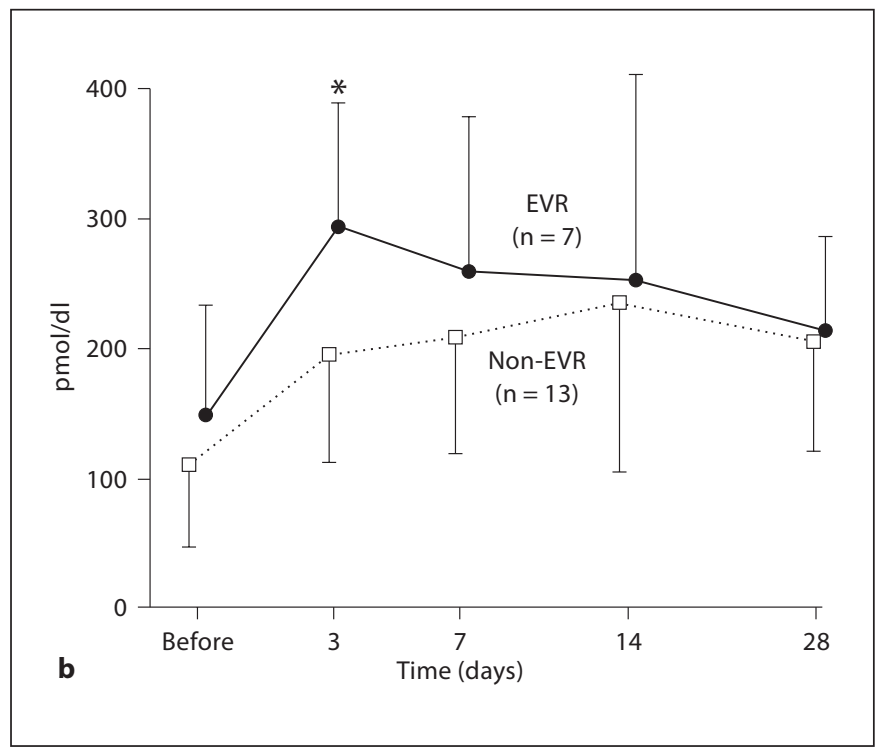

from the mutant group. b Serum 2-5AS activity in the mutant group. The solid line shows the mean serum 2-5AS level (+SD) in EVR patients from the mutant group. The dotted line shows the mean serum 2-5AS level (-SD) in non-EVR patients from the mutant group. * Significant difference $(\mathrm{p}<0.05)$ between the EVR and non-EVR patients from the mutant group.

a significant difference was obtained except on day 14 . In contrast, serial changes in serum 2-5AS levels were not different between the wild and mutant groups throughout the observation period. Therefore, it is possible that aa 70 substitution in the HCV core region influences IFNAR-2 expression by target cells before and during combination therapy, but not intracellular IFN signaling, in $\mathrm{CHC}$ patients with genotype $1 \mathrm{~b}$ and a high viral load.

In the wild group, the EVR rate was a high $70 \%$, and serial changes in IFNAR-2 expression by Mo were not significantly different between the EVR and non-EVR patients up to day 28. However, the serum level of 2-5AS, which is an antiviral molecule, was higher in the EVR patients. These findings suggested that EVR was easier to obtain if signal transduction by IFN proceeded smoothly in the target cells. Therefore, IFNAR-2 expression and IFN signaling in the target cells might be factors related to EVR in the wild group.

In the mutant group, the EVR rate was a low $35 \%$, and there were no significant differences in the changes in IFNAR-2 expression by Mo and serum 2-5AS levels between the EVR and non-EVR patients except on day 3. These findings suggested that not only IFNAR-2 expression but also IFN signaling was downregulated and dis- 
turbed in the target cells of the mutant group. Thus, EVR might be related to factors other than IFNAR-2 expression and IFN signaling in the target cells of the mutant group. Although EVR is not easy to obtain in the mutant group, other factors such as IFN-mediated innate and adaptive immune responses, may play a role in EVR patients from this group.

In the present study, we only evaluated IFNAR-2 expression and 2-5AS, which is one of final products of intracellular IFN signaling. However, the intracellular IFN signaling pathway has several molecules, including Jak1, STAT1, 2, ISGF3, and ISRE, while there are numerous products of ISGs $[8,9]$. Accordingly, these factors should be evaluated in $\mathrm{CHC}$ patients with aa 70 substitution in the HCV core region during combination therapy with PEG-IFN and RBV.

In conclusion, flow cytometry showed that aa 70 substitution in the core region of HCV downregulated baseline IFNAR-2 expression by Mo. After initiating combination therapy, this substitution might interfere with the induction of IFNAR-2 expression by Mo and with intracellular signal transduction by IFN. Further studies may lead to a better understanding of the pathophysiological role of IFNAR-2 in CHC patients with genotype $1 \mathrm{~b}$ and a high viral load receiving combination therapy with PEGIFN and RBV.

\section{References}

1 Manns MP, McHutchison JG, Gordon SC, Rustgi VK, Shiffman M, Reindollar R, Goodman ZD, Koury K, Ling M, Albrecht JK: Peginterferon alfa-2b plus ribavirin compared with interferon alfa-2b plus ribavirin for initial treatment of chronic hepatitis C: a randomized trial. Lancet 2001;358:958-965.

-2 Davis GL, Wong JB, McHutchison JG, Manns MP, Harvey J, Albrecht J: Early virologic response to treatment with peginterferon alfa$2 \mathrm{~b}$ plus ribavirin in patients with chronic hepatitis C. Hepatology 2003;38:645-652.

-3 Ferenci P, Fried MW, Shiffman ML, Smith CI, Marinos G, Gonçales FL Jr, Häussinger D, Diago M, Carosi G, Dhumeaux D, Craxì A, Chaneac M, Reddy KR: Predicting sustained virological responses in chronic hepatitis $\mathrm{C}$ patients treated with peginterferon alfa-2a (40 KD)/ribavirin. Hepatology 2005; 43:425-433.

4 Akuta N, Suzuki F, Kawamura Y, Yatsuji H, Sezaki H, Suzuki Y, Hosaka T, Kobayashi M, Kobayashi M, Arase Y, Ikeda K, Kumada H: Predictors of viral kinetics to peginterferon plus ribavirin combination therapy in Japanese patients infected with hepatitis $C$ virus genotype 1b. J Med Virol 2007;79:16861695.

5 Akuta N, Suzuki F, Sezaki H, Suzuki Y, Hosaka T, Someya T, Kobayashi M, Saitoh S, Watahiki S, Sato J, Matsuda M, Kobayashi M, Arase Y, Ikeda K, Kumada H: Association of amino acid substitution pattern in core protein of hepatitis $\mathrm{C}$ virus genotype $1 \mathrm{~b}$ high viral load and non-virological response to interferon-ribavirin combination therapy. Intervirology 2005;48:372-380.

6 Lin W, Kim SS, Yeung E, Kamegaya Y, Blackard JT, Kim KA, Holtzman MJ, Chung RT: Hepatitis $\mathrm{C}$ virus core protein blocks interferon signaling by interaction with STAT1 SH2 domain. J Med Virol 2006;80:92269235 .
7 Ciccaglione AR, Stellacci E, Marcantonio C, Muto V, Equestre M, Marsili G, Rapicetta M, Battistini A: Repression of interferon regulatory 1 by hepatitis $C$ virus core protein results in inhibition of antiviral and immunomodulatory genes. J Med Virol 2007;81: 202-214.

$\checkmark 8$ Chen X, Bhandari R, Vinkemeier U, Van Den Akker F, Darnell JE Jr, Kuriyan J: A reinterpretation of the dimerization interface of the N-terminal domains of STATs. Protein Sci 2003; 12:361-365.

$\checkmark 9$ Kisseleva T, Bhattacharya S, Braunstein J, Schindler CW: Signaling through the JAK/ STAT pathway, recent advances and future challenges. Gene 2002;285:1-24.

10 ten Hoeve J, de Jesus Ibarra-Sanchez M, Fu Y, Zhu W, Tremblay M, David M, Shuai K: Identification of a nuclear Stat 1 protein tyrosine phosphatase. Mol Cell Biol 2002;22: 5662-5668.

11 Novick D, Cohen B, Rubinstein M: The human interferon alpha/beta receptor: characterization and molecular cloning. Cell 1994 77:391-400.

12 Domanski P, Witte M, Kellum M, Rubinstein M, Hackett R, Pitha P, Colamonici OP: Cloning and expression of a long form of the beta subunit of the interferon alpha beta receptor that is required for signaling. J Biol Chem 1995;270:21606-20611.

13 Mizukoshi E, Kaneko S, Yanagi M, Ohno H, Kaji K, Terasaki S, Shimoda A, Matsushita E, Kobayashi K: Expression of interferon alpha/beta receptor in the liver of chronic hepatitis C patients. J Med Virol 1998;56:217223.

14 Yatsuhashi H, Fujino T, Matsumoto T, Inoue O, Koga M, Yano M: Immunohistochemical analysis of hepatic interferon alpha-beta receptor level: relationship between receptor expression and response to interferon therapy in patients with chronic hepatitis C. J Hepatol 1999;30:995-1003.
15 Mathai J, Shimoda K, Banner BF, Mori M, Bonkovsky HL, Barnard GF: IFN alpha-receptor mRNA expression in a United States sample with predominantly genotype 1a/I chronic hepatitis $\mathrm{C}$ liver biopsies correlates with response to IFN therapy. J Interferon Cytokine Res 1999;19:1011-1018.

16 Morita K, Tanaka K, Saito S, Kitamura T, Kiba T, Fujii T, Numata K, Sekihara H: Expression of interferon receptor genes in the liver as a predictor of interferon response in patients with chronic hepatitis C. J Med Virol 1999;58:359-365.

17 Yamaguchi Y, Hino K, Fujiwara D, Ren F, Katoh Y, Okita K: Expression of type I interferon receptor in liver and peripheral blood mononuclear cells in chronic hepatitis $\mathrm{C}$ patients. Dig Dis Sci 2002;47:1611-1617.

18 Tochizawa S, Akamatsu S, Sugiyama Y, Muraguchi $\mathrm{M}$, Ohmoto $\mathrm{Y}$, Ono $\mathrm{Y}$, Ishikawa $\mathrm{H}$, Tanigami A, Sumida T, Mori T: A flow cytometric method for determination of the interferon receptor IFNAR-2 subsets in peripheralbloodleukocyte subsets. JPharmacol Toxicol Method 2004;50:59-66.

19 Ren F, Hino K, Yamaguchi Y, Okazaki M, Kitase A, Satoh Y, Korenaga M, Okuda M, Okita K: Hepatitis C virus infection upregulates expression of the type I interferon receptor in human peripheral blood mononuclear cells. Hepatol Res 2003;26:15-22.

20 Knodell RG, Ishak KG, Black WC, Chen TS, Craig R,Kaplowitz N, Kiernan TW, Wollman J: Formulation and application of a numerical scoring system for assessing histological activity in asymptomatic chronic hepatitis. Hepatology 1981;1:431-435.

-21 Desmet VJ, Gerber M, Hoofnagle JH, Manns M, Scheuer PJ: Classification of chronic hepatitis: diagnosis, grading and staging. Hepatology 1994;19:1513-1520. 